Summary

Myroslava Hromovchuk. Limits of permissible intervention in biomedical studies of somatic human rights.

The article examines the features of the essence and content of the constitutional principles of human rights as a basis for legal regulation of biomedical research of somatic human rights. The author reveals the essence and content of international and national legal principles of human biomedical research. It was found that there are currently no standards of legal regulation of human rights protection during biomedical research at the national level and at the level of international acts in this field. It is pointed out that the issue of human and civil rights and freedoms in the conditions of formation and development of civil society in democratic states occupies a central place. It is established that the effective provision of constitutional rights and freedoms of man and citizen is associated with the need for restrictions in their implementation. It is determined that it is of fundamental importance that the attitude to law, to human rights and freedoms for the Ukrainian legal consciousness is impossible only through the awareness of a certain moral ideal as a goal in one's own life. Therefore, any legal problem for the Ukrainian mentality is inextricably linked with the values of goodness and justice, truth and humanity.

It is noted that the approaches to the definition of "freedom" have both common and different features or certain clarifications regarding certain manifestations. Without resorting to controversy about the truth or falsity of each of them, by generalizing their content, we can conclude that freedom, on the one hand, is an action according to their own desires, on the other - an action against them.

The limits of permissible intervention in conducting biomedical research with human participation have been studied, as well as the ethical examination of biomedical research as a way to protect human rights has been determined.

Key words: biomedical research, experiments on humans, human and civil rights, principles of human rights, principle of humanism, mechanism of human rights protection, medical experiment, somatic human rights.

DOI: 10.36695/2219-5521.4.2020.17

УДК 342.565.2/736.343.1(477)

\title{
М.А. МАРКУШ
}

Марія Андріївна Маркуш, кандидат юридичних наук, докторантка Інституту законодавства Верховної Ради України*

ORCID: 0000-0002-7642-1026

\section{КОНЦЕПТУАЛЬНІ ПРОБЛЕМИ ПОБУДОВИ КОНСТИТУЦІЙНО-ПРАВОВОЇ МОДЕЛІ ЗМАГАЛЬНОСТІ КРИМІНАЛЬНОГО ПРОЦЕСУ УКРАЇНИ}

Постановка проблеми. Наукове осмислення конституційно-правової суті та функціональності сучасної моделі кримінального процесу України може бути сутнісним тільки тоді, коли ііі концепція беззаперечно грунтується на положеннях Конституції України та міжнародно-правових стандартах у сфері захисту прав людини і здійснюється передусім на основі конституційних засад: верховенства права, незалежності суду, права на захист, змагальності та інших основних засад судочинства. В умовах реформування правової системи України у рамках євроінтеграційного процесу відбувається конвергенція вітчизняної правової системи 3 правовою системою ЄС, а тому актуальність дослідження концептуальних основ кримінального процесу України на основі міжнародно-правових актів щодо захисту прав людини об' єктивно посилюється.

Метою статті $є$ науково обгрунтувати конституційно-правову природу концепції побудови змагальної моделі кримінального процесу України на підставі конституційної засади змагальності судочинства та запропонувати результати його теоретичного моделювання на основі Конституції України.

Наукова новизна статті полягає у формулюванні концепції побудови конституційної моделі змагальності кримінального процесу та визначенні їі місця у правовій доктрині. Стаття присвячена концептуальним проблемам змагальної моделі кримінального процесу України, закріпленої у чинному Кримінальному процесуальному кодексі України (далі - КПК України). У статті проаналізовано вітчизняний досвід правового регулювання змагальності кримінального процесу, висвітлено окремі проблеми, запропоновано шляхи їх вирішення та зроблено висновок про фактичну нерівноправність сторін у кримінальному провадженні, а також визначено законодавчу модель кримінального процесу України.

Виклад основного матеріалу. Концепція побудови змагальної моделі кримінального процесу України грунтується насамперед на положеннях Основного Закону України та міжнародно-правових актів, які є частиною національного законодавства на основі ч. 1 ст. 9 Конституції України, а саме: ст. 10, ст. 11 Загальної декларації прав людини від 10 грудня 1948 р. ${ }^{1}$, ст. 6 Конвенції про захист прав людини і основоположних свобод від 4 листопада 1950 р. ${ }^{2}$ та ст. 14 Міжнародного пакту про громадянські і політичні права від 16 грудня 1966 р. ${ }^{3}$, які закріплюють право на незалежний і безсторонній суд, право на захист, права обвинуваченого бути присутнім під час судового розгляду та брати активну участь у дослідженні доказів тощо. Концепція

(C) М.А. Маркуш, 2020

* Mariia Markush, Ph.D. in Law, Doctoral Candidate of the Legislation Institute of the Verkhovna Rada of Ukraine 
судово-правової реформи в Україні від 28 квітня 1992 р. одним із основних принципів цієї реформи назвала «створення такого судочинства, яке створило б умови для дійсної змагальності» ${ }^{4}$, а Конституція України закріпила змагальність як одну із основних засад судочинства (п. 3 ч. 2 ст. 129)5.

Засада змагальності судочинства була визначена й у Кримінально-процесуальному кодексі 1960 р.6, який у 2001 р. було доповнено ст. 16-17.

Міжнародні стандарти прав людини, які закріплені в основних міжнародно-правових документах, $є$ системою правових приписів, що розкривають ідею прав людини ${ }^{8}$ і втілюються у національних правових

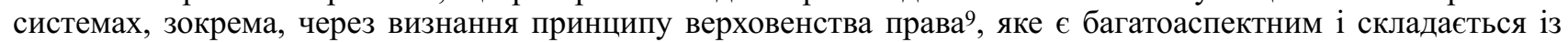
компонентів, що утворюють його зміст ${ }^{10}$.

Розвиток принципу верховенства права на міжнародному рівні зумовлений принципом верховенства міжнародного права над національним правом. У світі склалася дієва взаємодія міжнародного та національного права через принцип верховенства права: а) принцип верховенства права визнається та гарантується на національному рівні певної держави; б) держава визнає верховенство міжнародного права над своїм національним правом; в) міжнародне право акумулює досягнення національного права, вдосконалює і поширює ïx, використовуючи принцип верховенства міжнародного права над національним. Тому національна і міжнародна правові системи, будучи тісно взаємопов'язаними через принцип верховенства права, живуть і розвиваються, взаємодоповнюючи і збагачуючи теоретичними досягненнями одна одну: «Верховенство права, у розумінні міжнародного права, передбачає дотримання принципу правління, відповідно до якого всі особи, установи і структури, державні і приватні, в тому числі сама держава, функціонують відповідно до законів, які були публічно прийняті, в рівній мірі виконуються і незалежно реалізуються судовими органами і які сумісні 3 міжнародними нормами та стандартами в області прав людини» ${ }^{11}$.

Поряд 3 теоретичними розробками у напрямі вдосконалення процесуального законодавства України постає питання вирішення проблем імплементації європейських правових стандартів у сфері кримінального судочинства у кримінальний процес України та вироблення концепції моделі вітчизняного кримінального процесу. Теоретичні проблеми концепції змагальності і побудови моделі кримінального процесу України та їх вирішення досліджували Л.О. Богословська, Т.В. Варфоломесва, В.Г. Гончаренко, В.В. Городовенко, Ю.М. Грошевий, Л.М. Лобойко, В.Т. Маляренко, В.Т. Нор, В.П. Півненко, В.О. Попелюшко, Б.В. Романюк, М.I. Сірий, О.М. Толочко, Є.О. Мірошниченко, М.А. Погорецький, В.П. Шибіко, М.Є Шумило, О.Г. Яновська та інші вчені.

Асоціація України до ЄС викликала необхідність сприйняття низки правових принципів, насамперед принципу верховенства права та засади змагальності у кримінальному процесі України, через міжнародне право, тому на їх сучасне розуміння докорінно вплинули такі чинники, як: 1) кодифікація міжнародного права та його прогресивний розвиток; 2) дотримання міжнародно-правових зобов’язань України як суб'єкта міжнародного права у сфері захисту прав людини, які випливають як із міжнародних договорів, так і 3 міжнародного звичаєвого права; 3) відповідальність України як суб'єкта міжнародного права за виконання взятих на себе міжнародних зобов'язань.

Конституційний принцип верховенства права, що визнається і діє в Україні (ст. 8), є основоположним для всіх галузей права в Україні, у тому числі й кримінального процесуального права. На сучасному етапі розвитку правової системи України, потребах в її удосконаленні на перспективу та 3 метою адаптації до європейського законодавства, перед законодавцем і українськими вченими постає завдання забезпечити відповідність національного законодавства міжнародно-правовим стандартам, не руйнуючи наявні ефективні правові механізми захисту прав, свобод і законних інтересів учасників кримінального судочинства 12 . При цьому повинні враховуватися положення ЄКПЛ та практика ЄСПЛ. Теоретичні аспекти вивчення місця ЄКПЛ та практики Свропейського суду з прав людини в правовій системі України грунтуються на положеннях Конституції України (ст. ст. 3, 8-9, Розділ VIII «Правосуддя») та законах України, зокрема Законі України «Про міжнародні договори»13. Тому побудова конституційно-правової моделі змагального кримінального судочинства в Україні має грунтуватися на конституційних засадах, передусім засадах пріоритету прав і свобод людини, верховенства права, верховенства Конституції України, основних засадах судочинства та вимогах удосконалення і впровадження нових процедур у вітчизняне правосуддя на основі міжнародних стандартів щодо захисту прав людини, правових принципів і цінностей у сфері кримінального процесу.

Аналіз чинного кримінального-процесуального законодавства України породжує багато дискусій, виявляє прогалини та проблеми у кримінальній юстиції, тому серед українських учених і практиків не припиняється полеміка щодо теоретичного осмислення положень чинного КПК України з метою напрацювання пропозицій і рекомендацій стосовно його удосконалення і покращення практичного застосування, що є цілком виправданим, адже сучасне кримінальне процесуальне законодавство отримало значну кількість новел, які $\epsilon$ досить новими для теорії конституційного права, кримінально-процесуального права та для правозастосовної практики, а окремі з цих нововведень не відповідають Конституції України, ЄКПЛ та іншим актам ЄС.

Визначальним в утвердженні верховенства права, змагальної моделі вітчизняного кримінального процесу та європейських підходів до розуміння прав людини в практиці українського судочинства став Закон України від 23 лютого 2006 р. «Про виконання рішень та застосування практики Європейського суду з прав людини» № 3477- IV (зі змінами) ${ }^{14}$, ст. 17 якого зобов’язує суди України при розгляді ними справ застосовувати Конвенцію про захист прав людини і основоположних свобод (ЄКПЛ) та практику Європейського Суду 3 прав людини (ССПЛ) як джерело права. Тому суди України мають не тільки керуватися формальним тлу- 
маченням норм права, а й зобов'язані посилатися на правові позиції (висновки) ЄСПЛ як на безпосереднє джерело права і додержуватися притаманної рішенням ССПЛ ідей справедливості і гуманності ${ }^{15}$, втілювати iï у своїх рішеннях ${ }^{16}$, посилатися на СКПЛ і застосовувати у своїх рішеннях практику ССПЛ17.

Професор Оксфордського університету Альберт Вен Дайсі цілком слушно вважає, що там, де є дискреція, є простір для свавільності, однак жодна людина не перебуває понад законом ${ }^{18}$ i саме держава має гарантувати особі ефективні засоби правового захисту прав і свобод людини, і таке право має встановлюватися судовим або іншим компетентним органом, передбаченим правовою системою держави (п. 2 Міжнародного пакту про громадянські і політичні права) ${ }^{19}$. Кримінально-процесуальна діяльність як складова загальнодержавної діяльності має бути спрямована на забезпечення конституційних положень про пріоритетність прав і свобод людини і їх гарантій та здійснення своєї охоронної та відновлювальної функцій прав і свобод людини, захисту ії інтересів виключно у зв'язку і в межах кримінального провадження. Тому кримінальне судочинство є засобом захисту особи, суспільства та держави від кримінальних правопорушень, а належна регламентація та здійснення кримінально-процесуальної діяльності - гарантією охорони прав, свобод і законних інтересів учасників кримінального провадження. При цьому охорона прав, свобод і законних інтересів учасників кримінального провадження як необхідна умова і один із засобів здійснення законного, неупередженого розслідування та судового розгляду, що може бути справедливим лише за умови втілення конституційної засади змагальності судочинства у всіх стадіях кримінального процесу 20 , зробить його дійсно змагальним. Ідея змагальної моделі кримінального судочинства - одна із центральних та найгостріших у науці кримінального процесу і є предметом численних дискусій та публікацій.

Конституційна засада змагальності судочинства (п. 3 ч. 2 ст. 129 Основного Закону України) є тією концептуальною основою побудови вітчизняного кримінального процесу, повноцінне втілення якої у всіх стадіях судочинства змінить його модель на змагальну. Ідеологічний стрижень змагальної моделі кримінального процесу лежить у двох протилежних інтересах, які перебувають у діалектичній єдності та боротьбі протилежностей, - публічному і приватному. Публічний інтерес полягає в покаранні винного: «impunitum non relinqui facinus», а приватний - у створенні гарантій суб'єктивних прав і свобод, права на захист: «innocentem non condamnari».

Занадто вузько сприйнятий публічний інтерес призводить до заперечення цінності формальних обмежень і відсуває на другий план права і свободи особи та їх захист у сфері кримінального судочинства. I навпаки, інтереси свободи громадян вимагають стриманості у кримінальному переслідуванні особи та певного критицизму під час здійснення правосуддя у кримінальному процесі; швидше виправдання винного, ніж засудження невинуватого. Тому концепція змагального кримінального процесу має розпочинатись $\mathrm{i}$ завершуватись ідеєю поєднання цих інтересів, бажано з урахуванням національних традицій, на що вказували і експерти Ради Свропи у своєму висновку21. Зокрема, у цьому висновку вони акцентували на тому, що кримінальне законодавство відіграє важливу роль у забезпеченні дотримання верховенства права у суспільстві, бо ті, хто порушує це законодавство, мають притягатися до кримінальної відповідальності. Якщо винних у вчиненні злочинів залишати безкарними, закон поступається місцем сваволі (п. 3). Отже, законодавча політика, зокрема у сфері кримінальної юстиції, балансує між публічними та приватними інтересами, стаючи відображенням відповідної державної ідеології у сфері права (державно-охоронної, індивідуалістичної, консервативної, ліберальної, публічно-правової або приватноправової тощо).

Вітчизняна доктрина змагального кримінального процесу має тривалий період свого формування, що вплинуло на неоднозначність підходів до розуміння їі сутності. Характерними ознаками змагальності судового процесу є: наявність сторін із протилежними матеріально-правовими інтересами; наділення їх рівними процесуальними правами; наявність незалежного від сторін арбітра - суду, завданням якого є вирішення правового спору по суті.

Набрання чинності Кримінальним процесуальним кодексом України (далі - КПК України) ${ }^{22}$ для окремих вчених стало підставою вважати, що вітчизняне кримінальне судочинство повністю сприйняло змагальну модель своєї побудови. При цьому КПК України певним чином віддзеркалює домінуючі ідейні уявлення (концептуальні положення) щодо сутності кримінального процесу як змагального засобу вирішення кримінально-правового конфлікту та відбиває такі основні напрями кримінальної процесуальної політики, як пошук компромісів між публічними і приватними інтересами - вирішенням публічних завдань кримінального процесу і забезпеченням приватного інтересу щодо захисту прав та свобод людини у царині кримінального провадження, справедливості й розумності у застосуванні заходів забезпечення кримінального провадження, гуманізації кримінального процесуального законодавства та практики його застосування, запровадження процедур примирення тощо.

Слід сказати, що чинний КПК Украӥни запровадив істотно змінену модель кримінального процесу. Значна кількість процесуальних інститутів зазнали змін, введено нові інститути, які до цього часу були невідомі вітчизняному кримінальному процесуальному праву. Також законодавець відмовився від завдання швидкого та повного розкриття злочинів на користь забезпечення швидкого, повного та неупередженого розслідування і судового розгляду.

Формулювання і порядок розташування системи завдань кримінального провадження у ст. 2 КПК України, на наш погляд, відбувалось швидше з ідеологічним підтекстом, ніж відповідно до їх юридичного змісту, що скоріше підтверджує спробу законодавця визнати прагнення зміни парадигми моделі вітчизняного кримінального процесу і його переходу від змішаного до змагального типу. Водночас завдання швидкого та 
повного розкриття злочинів, викриття винних і забезпечення правильного застосування закону з тим, щоб кожний, хто вчинив злочин, був притягнутий до відповідальності й жоден невинуватий не був покараний (ст. 2 КПК України 1960 р.) не може бути завданням сторони захисту, а притягнення до відповідальності кожного, хто вчинив злочин, є завданням нездійсненним.

При цьому тісний взаємозв'язок кримінального процесу з кримінальним правом, його функціональна роль у забезпеченні реалізації кримінально-правових норм є необхідними підставами для встановлення у кримінальному провадженні події кримінального правопорушення, суб'єкта, що його вчинила, вирішення питання про його відповідальність і покарання. Тому наведені положення вочевидь є завданнями сторони обвинувачення у кримінальному процесі. Водночас там, де постає завдання встановлення провини особи у вчиненні кримінального правопорушення, їі покарання, має виникати завдання захисту прав, свобод і законних інтересів особи та недопущення притягнення до відповідальності та покарання осіб, які не вчиняли кримінальних правопорушень. При цьому обмеження прав і свобод людини і громадянина заходами процесуального примусу, передбаченими КПК України, має допускатися тільки з метою вирішення завдань кримінального процесу та відповідно до його принципів, передбачених цим кодексом²3.

Для аналізу реального стану змагальності сторін як засади кримінального судочинства слід детальніше проаналізувати реалізацію іiі елементів у кримінальних процесуальних нормах. У ст. 22 КПК України закріплено такі елементи принципу змагальності сторін, як: наявність сторони обвинувачення та сторони захисту; наявність закріплених процесуальних засобів діяльності сторони обвинувачення та сторони захисту; наявність та чітке відокремлення функцій публічного обвинувачення, захисту та судового розгляду; наявність об'єктивного та неупередженого суду. Аналіз такого елементу, як закріплення у КПК України процесуальних засобів здійснення діяльності сторони обвинувачення та сторони захисту дає підстави для висновку про очевидну непропорційність можливостей сторони обвинувачення і захисту щодо пошуку та надання доказів. Дії сторони захисту та потерпілого, які здатні забезпечити подання до суду належних і допустимих доказів, визначені в ч. 3 ст. 93 КПК України. Однак в КПК України (ч. ч. 1, 3 ст. 93 КПК України) не конкретизовано дії сторони захисту та не унормовано порядок, механізми і гарантії їх реалізації (здійснення), які мали б забезпечити збирання і подання до суду належних і допустимих доказів стороною захисту. Відтак, виходячи 3 положень ст. 86 КПК України, докази, одержані стороною захисту в порядку ч. 3 ст. 93 КПК України, можуть бути визнані судом недопустимими, навіть якщо вони виправдовують чи пом'якшують вину обвинуваченого (підсудного). При цьому клопотання сторони захисту про збір, надання чи забезпечення доказів не є обов'язковими для задоволення слідчим чи прокурором, однак постанова слідчого, прокурора про відмову в задоволенні клопотання про проведення слідчих (розшукових) дій, негласних слідчих (розшукових) дій може бути оскаржена слідчому судді. У цьому контексті цікавим є підхід ЄСПЛ, який у своїх рішеннях констатував, що кожній стороні повинна бути надана належна можливість, щоб відстоювати свій інтерес у справі, включаючи подання своїх доказів, за умови, що не ставлять ії у невигідне становище стосовно суперника (Рішення ЄСПЛ у справі «Ноймайстер проти Австрії» (Neumeister v. Austria), від 27 червня 1968 р., п. 4, Серія А, № 8. П.П. 22-25)24.

ЄСПЛ допускає незначну нерівність сторін, яка в загальному не впливає на процес та їх права (рішення ССПЛ у справі «Боргерс проти Бельгї» (Borgers v. Belgium) від 30 жовтня 1991 р., Серія А N $214-\mathrm{B}$. P.p. 24-27 in fine) ${ }^{25}$. Центральним елементом засади змагальності є наявність об'єктивного та неупередженого суду. ССПЛ не аналізує засаду змагальності судового процесу в аспекті активної чи пасивної ролі суду. Для ЄСПЛ з огляду на вимоги ЄКПЛ важливо, щоб сторони дійсно, а не формально були наділені рівними і достатніми правами для відстоювання своєї позиції, а суд був неупередженим суб'єктивно й об'єктивно. Перше передбачає особисту незаінтересованість і неупередженість судді як інституту здійснення правосуддя. При цьому об’єктивна неупередженість суду розуміється як достатність гарантій, що виключають будьякі законні сумніви стосовно упередженості і необ'єктивності судді (Рішення ЄСПЛ від 24 листопада 2000 р. у справі «Дактарас проти Литви» (Dactaras v. Lithuania) ${ }^{26}$.

Вирішальним критерієм для визначення ступеня змагальності певної процедури, як зазначалося, $\epsilon$ реальний обсяг повноважень, наданих кожній зі сторін провадження та забезпечення гарантій їх реалізації. У кримінальному процесі крім сторін кримінального провадження, як зазначалося, важливим суб'єктом здійснення кримінально-процесуальної діяльності є суд, який забезпечує змагальний процес, тому будучи об'єктивним і неупередженим, зобов'язаний створювати необхідні умови для реалізації сторонами їх процесуальних прав та виконання процесуальних обов'язків (ч. 6 ст. 22 КПК України) та, виконуючи вимоги принципу диспозитивності, має вирішувати лише ті питання, які винесені на його розгляд сторонами і віднесені законом до його повноважень (ч. 3 ст. 26 КПК України).

Завдання кримінального провадження, безперечно, є продовженням і конкретизацією мети кримінального процесу, вони забезпечуються реалізацією кримінально-правових норм, є специфічними саме для кримінального провадження та відображають модель кримінального процесу і зумовлені нею. Саме вони видозмінюються зі зміною концептуальних основ кримінального процесу, тому з урахуванням цих вимог реалізація кримінально-правових норм, кримінальної відповідальності у змагальному кримінальному провадженні має відбуватись у межах швидкого, повного та неупередженого розслідування і судового розгляду 3 максимальним дотриманням прав і свобод та законних інтересів учасників кримінального провадження.

Повне й неупереджене досудове розслідування і судовий розгляд мають дуалістичний характер - дають можливість забезпечити вирішення основного завдання кримінального провадження двоєдиним шляхом: а) 
притягнення до кримінальної відповідальності особи, яка вчинила кримінальне правопорушення; б) недопущення обвинувачення або засудження жодного невинуватого 27 . Законодавче закріплення моделі кримінального провадження з урахуванням концептуальних положень, що грунтуються на засадничих положеннях Конституції України та міжнародних стандартах у сфері захисту прав людини, дасть можливість побудувати конституційно-правову модель змагальності кримінального процесу в Україні, одержати чітке уявлення про модель кримінального судочинства та спрямувати суб'єктів правозастосування на здійснення їх діяльності на основі пріоритету прав людини.

Висновки. 3 наведеного аналізу можна констатувати, щзо тенденщії розвитку кримінально-процесуального законодавства Украӥни наближають вітчизняне кримінальне судочинство до публічно-змагальної моделі кримінального процесу Украӥни з елементами англосаксонського типу 28 , яка має трунтуватися насамперед на конституизійних концептуальних основах.

Концептуальними основами сучасного кримінального процесу України має стати система теоретичних, правових та праксеологічних положень загального характеру, що закріплені в положеннях міжнародноправових документів, які визначають міжнародні стандарти в сфері захисту прав людини та положення Конституції України, що безпосередньо впливають на зміст і модель вітчизняного кримінального процесу. Базовою основою концепції кримінального процесу України є Конституція України, яка визначає основу та формат будь-якого правового явища у державі. Незважаючи на те, що концепція передусім відображає теоретичні основи, вихідні засади та передумови певної діяльності, вона формує базисні поняття, схеми та форми, відповідно до яких ця діяльність реалізується. Таким чином, зміна концептуальних основ будь-якого виду діяльності, у тому числі кримінально-процесуальної, є найбільш радикальним реформуванням, оскільки призводить до необхідності відмови від обгрунтованих раніше постулатів і стандартів мислення та дій, до зміни вихідних понять, які забезпечують цілісне сприйняття системи цієї діяльності, а тому повинна грунтуватися на положеннях Конституції України, що дасть змогу побудувати конституційно-правову модель змагального кримінального процесу в Україні.

1 Загальна декларація прав людини від 10 грудня 1948 p. URL: http://zakon4.rada.gov.ua/laws/show/995_015

2 Конвенція про захист прав людини і основоположних свобод від 4 листопада 1950 p. URL: http://zakon4.rada.gov.ua/ laws/show/995_004

3 Міжнародний пакт про громадянські і політичні права від 16 грудня 1966 p. URL: http://zakon4.rada.gov.ua/laws/ show/995 043

4 Концепція судово-правової реформи в Україні від 28 квітня 1992 p. URL: http://zakon4.rada.gov.ua/laws/show/2296-12

5 Конституція України : офіційне видання. Київ: Алерта, 2019. 112 с.

${ }^{6}$ Кримінально-процесуальний кодекс України : Закон України від 28 грудня 1960 р. Відомості Верховної Ради України. 1961. № 2. Ст. 15. URL: https://zakon.rada.gov.ua/laws/show/1001-05\#Text

7 Про внесення змін до Кримінально-процесуального кодексу України: Закон України № 2533-ІІІ від 21 червня 2001 р. Відомості Верховної Ради України. 2001. № 34-35.

8 Особливості міжнародних стандартів щодо прав та свобод людини і громадянина. URL: http://bibliofond.ru/view.aspx? $\mathrm{id}=439567$

9 Банчук О.А., Куйбіда Р.О. Вимоги статті 6 Конвенції про захист прав людини та основних свобод до процедури здійснення судочинства. Київ : ІКЦ «Леста», 2005. С. 51. 116 с.

10 Мірошниченко О.А. Принцип верховенства права у міжнародному публічному праві. Форум права. 2012. № 1. С. $644-647$.

11 Кримінальний процес: підручник / Ю.М. Грошевий, В.Я. Тацій, А.Р. Туманянц та ін.; за ред. В.Я. Тація, Ю.М. Грошевого, О.В. Капліної, О.Г. Шило. Харків: Право, 2013. С. 64. 824 с. $416 \mathrm{c}$.

12 Уваров В.Г. Міжнародно-правові стандарти у кримінальному процесі України : монографія. Харків : НікаНова, 2014.

13 Про міжнародні договори. Закон України від 29 червня 2004 р. № 1906-IV (зі змінами). Відомості Верховної Ради України. 2004. № 50. Ст. 540.

14 Про виконання рішень та застосування практики Європейського суду з прав людини. Закон України від 23 лютого 2006 р. № 3477- IV (зі змінами). Відомості Верховної Ради Украӥни. 2006. № 30. Ст. 250.

15 Шевчук С.В. Порівняльне прецедентне право з прав людини. Київ : Реферат, 2002. 344 с.

16 Колісник О.В. Удосконалення здійснення судочинства в Україні в контексті практики Європейського суду з прав людини. Науковий вісник Чернівецького університету : зб. наук. праць. Чернівці, 2008. С. 46-50.

17 Вільчик Т.Б. Конституційне право на правову допомогу адвоката у країнах Європейського Союзу та в Україні : монографія. Харків : Право, 2015. 400 с.

18 Дайси А.В. Основы государственного права Англии: Введение в изучение английской конституции; перевод, дополн. по 6-му англ. изд. 2-е изд. Москва: Тип. т-ва И.Д. Сытина, 1907. 707 с. С. 211.

19 Міжнародний пакт про громадянські і політичні права : Прийнятий резолюцією 2200 А (XXI) Генеральної Асамблеї ООН від 16 грудня 1966 р., ратифікований Указом Президії Верховної Ради Української РСР № 2148-08 від 19 жовтня 1973 р. Права людини : зб. док. / укл. В.С. Семенов, О.Н. Ярмиш та ін. Харків : Ун-т внутр. справ, 1997. С. 4-25.

20 Див.: абзац восьмий пункту 9 мотивувальної частини Рішення Конституційного Суду України у справі за конституційним поданням Верховного Суду України щодо відповідності Конституції України (конституційності) положень частини третьої статті 120, частини шостої статті 234, частини третьої статті 236 Кримінально-процесуального кодексу України (справа про розгляд судом окремих постанов слідчого і прокурора) від 30 січня 2003 р. № 3-рп/2003; абзаци другий, четвертий пункту 5 мотивувальної частини) Рішення Конституційного Суду України у справі за конституційним поданням Верховного Суду України щодо відповідності Конституції України (конституційності) положень частин сьомої, дев'ятої, пункту 2 частини шістнадцятої статті 236-8 Кримінально-процесуального кодексу України від 30 червня 2009 р. № 16-рп/2009; Рішення ЄСПЛ від 
2 березня 1987 р. у справі Моннелл і Моріс проти Об'єднаного Королівства (Monnell and Morris v United Kingdom). Judgement of 2 Marth 1987. Series A. № 115. P. 25-94. para 5570). URL: http://echr.ketse.com/doc/9562.81-9818.82-en-19870302/view/; Piшeння ЄСПЛ ЕСН1961-S-001 від 1 липня 1961 р. у справі Ловлесс проти Ірландії (Lawless v. Ireland URL: http://hudoc.echr.coe.int/ app/conversion/pdf/?library=ECHR\&id=001-57516\&filename=001-57516.pdf\&TID=epcmxtpacx; Маркуш М.А. Конституційноправові основи кримінально-процесуальної доктрини в аспекті засади змагальності. Наукові записки Інституту законодавства Верховної Ради Украӥни. 2019. № 2. С. 28-41.

21 Висновок експертів Ради Європи щодо проєкту Кримінального процесуального кодексу України (Страсбург, 2 листопада 2011 p.). URL: http://www.coe.kiev.ua/news/2012/01/Opinion\%20on\%20Draft\%20CPC\%20UA\%20Ukr.pdf

22 Кримінальний процесуальний кодекс України. Київ: Видавець Паливода А.В., 2018. 404 с.

23 Беспалько І.Л. Система принципів кримінального процесу та проблема їх класифікації : монографія. Харків: Вид-во «ФІНH», 2011. 216 c. C. 149.

${ }_{24}$ Рішення ЄСПЛ у справі «Ноймайстер проти Австрї̈» (Neumeister v. Austria), від 27 червня 1968 р., п. 4, Серія А, № 8. П.п. 22-25. Interights Manual for Lawyers - Right to A Fair Trial under the ECHR (Article 6). 2007.90 p. P. 36.

25 Рішення ЄСПЛ у справі «Боргерс проти Бельгіï» (Borger v. Belgium), від 30 жовтня 1991 р., Серія А N 214-B. Р.p. 24-27 in fine. Interights Manual for Lawyers - Right to A Fair Trial under the ECHR (Article 6). 2007. 90 p. P. 36.

26 Рішення ЄСПЛ від 24 листопада 2000 р. у справі «Дактарас проти Литви» (Dactaras v.Lithuania). URL: http://zakon5. rada.gov.ua/laws/show/980_005

27 Кримінальний процесуальний кодекс України: наук.-практ. коментар / за заг. ред. В.Г. Гончаренка, В.Т. Нора, М.Є. Шумила. Київ : Юстініан, 2012. 1224 с. С. 19.

28 Яновська О.Г. Теоретичні та організаційні засади функціонування і розвитку змагального кримінального судочинства : автореф. дис. ... д-ра юрид. наук : 12.00.10. Київ, 2011. 36 с. С. 5.

\title{
Резюме
}

Маркуш М.А. Концептуальні проблеми побудови конституційно-правової моделі змагальності кримінального процесу України.

У статті представлено концепцію теоретичного моделювання змагальності кримінального процесу України, яка грунтується на системі теоретичних, правових та праксеологічних положень загального характеру, що закріплені в положеннях міжнародно-правових документів, які визначають міжнародні стандарти в сфері захисту прав людини та положеннях Конституції України. Зокрема, визначено суть та теоретичні основи змагальної моделі кримінального судочинства України, окреслено окремі проблеми законодавчого забезпечення реалізації конституційної засади змагальності стороною захисту в кримінальному провадженні та запропоновано шляхи їх вирішення.

Ключові слова: Конституція України, концепція, конвергенція, кримінальне судочинство, конституційна модель змагальності кримінального процесу, міжнародно-правові стандарти щодо захисту прав людини, правова система ЄС.

\section{Резюме}

\begin{abstract}
Маркуш М.А. Концептуальные проблемы построения конституционно-правовой модели состязательности уголовного процесса Украины.

В статье представлены результаты концепции теоретического моделирования состязательности уголовного процесса Украины, которая основывается на системе теоретических, правовых и праксеологических положений общего характера, закрепленных в положениях международно-правовых документов, определяющих международные стандарты в сфере защиты прав человека, а также в положениях Конституции Украины. В частности, определены сущность и теоретические основания состязательной модели уголовного судопроизводства, очерчены отдельные проблемы законодательного обеспечения реализации конституционного начала состязательности стороной защиты в уголовном судопроизводстве и предложены пути их реше-
\end{abstract} ния.

Ключевые слова: Конституция Украины, конституционное право, концепция, конвергенция, уголовное судопроизводство, конституционная модель состязательности уголовного процесса, международно-правовые стандарты защиты прав человека, правовая система ЕС.

\section{Summary}

Mariia Markush. Conceptual problems of construction of the constitutional and legal model of adversarial proceedings of the criminal process of Ukraine.

The article is devoted to the conceptual problems of building a competitive model of the criminal process of Ukraine under the current Criminal Procedure Code of Ukraine (the CPC of Ukraine).

Scientific understanding of the constitutional and legal essence and functionality of the modern model of the criminal process of Ukraine can be essential only when its concept is unquestionably based on the provisions of the Constitution of Ukraine and international legal standards and is carried out in terms of constitutional principles: rule of law, independence of court, right to protection. as well as the principles of adversarial and other principles of justice. In the context of reforming the legal system of Ukraine in the European integration process, there is a convergence of the domestic legal system with the EU legal system, so the relevance of the study of the conceptual framework of the criminal process of Ukraine on the basis of international human rights law objectively increases.

The Association of Ukraine to the EU necessitated the adoption of a number of legal principles, first of all the rule of law and adversarial principles, through international law, and not exclusively through national prism, because their modern understanding is greatly influenced by such judgemental factors as: 1) codification of international law and its progressive development; 2) compliance with the international legal obligations of Ukraine as a subject of international law in the field of human rights protection, arising from both international treaties and customary international law; 3) the responsibility of Ukraine as a subject of international law for the implementation of international obligations. 
The article analyzes the national experience of legal regulation of adversarial proceedings in criminal proceedings, explores various scientific approaches to this problem and concludes on the actual inequality of the parties in criminal proceedings, as well as defines the legislative model of the criminal process in Ukraine. The analysis of international legal acts, provisions of the Constitution of Ukraine, CPC of Ukraine and positions of procedural scholars given in the article gives grounds to state that the tendencies of development of criminal procedure legislation of Ukraine bring the criminal process of Ukraine closer to the public-competitive model with Anglo-Saxon elements on an international and constitutional conceptual basis.

The conceptual foundations of the modern criminal process of Ukraine are a system of theoretical, legal and praxeological provisions of general nature, enshrined in the provisions of international legal documents that define international standards in the field of human rights and the Constitution of Ukraine, which directly affect the content and model of domestic criminal process. The basic basis of the concept of the criminal process of Ukraine is the Constitution of Ukraine, which determines the basis and form of any legal phenomenon in the state. Despite the fact that the concept primarily reflects the theoretical foundations, basic principles and prerequisites of a particular activity, it forms the basic concepts, schemes and forms according to which this activity is implemented. Thus, changing the conceptual basis of criminal procedure is its most radical reform, as it leads to the need to abandon previously substantiated postulates and standards of thinking and action, to change the basic concepts that ensure a holistic perception of the system of this activity, and therefore should be based on Constitution of Ukraine, which will build a constitutional and legal model of adversarial criminal proceedings in Ukraine.

Key words: Constitution of Ukraine, concept, convergence, criminal proceedings, constitutional model of adversarial criminal process, international legal standards for human rights protection, EU legal system.

DOI: $10.36695 / 2219-5521.4 .2020 .18$

УДК 342.7

\section{Л.В. МІХНЕВИЧ}

Людмила Володимирівна Міхневич, кандидат юридичних наук, доцент, завідувач кафредри Київського національного економічного університету ім. Вадима Гетьмана*

ORCID: 0000-0002-4774-079X

\section{КОНСТИТУЦІЙНЕ ПРАВО НА ТАЄМНИЦЮ ЛИСТУВАННЯ, ТЕЛЕФОННИХ РОЗМОВ, ТЕЛЕГРАФНОÏ ТА ІНШОÏ КОРЕСПОНДЕНЦІЇ ОКРЕМИХ КАТЕГОРІЙ ОСІБ}

Постановка проблеми. Рівень забезпечення прав і свобод людини є показником рівня свободи особи в державі та виконання державою своїх зобов'язань перед людьми. Право особи на таємницю листування, телефонних розмов, телеграфної та іншої кореспонденції, будучи одним із основоположних та невід'ємних прав людини, гарантує її свободу й особисту недоторканність, а його забезпечення набуває особливого значення. Це зумовлено тим, що листування, телефонні розмови, телеграфна та інша кореспонденція є досить важливими засобами спілкування людей як в особистій, так і в робочій сферах. Втім, право на таємницю кореспонденції не $\epsilon$ абсолютним. Міжнародні документи та акти національного законодавства встановлюють певні застереження. Відповідно до Конвенції про захист прав людини та основоположних свобод (далі Конвенція) обмеження здійснення цього права можливе згідно із законом у випадках, необхідних у демократичному суспільстві в інтересах національної та громадської безпеки чи економічного добробуту країни, для запобігання заворушенням чи злочинам, для захисту здоров'я чи моралі або для захисту прав і свобод інших осібㅌ. Конституцією України визначено, що винятки можуть бути встановлені лише судом у випадках, передбачених законом, з метою запобігти злочинові чи з'ясувати істину під час розслідування кримінальної справи, якщо іншими способами одержати інформацію неможливо 2 . Однак на практиці трапляються непоодинокі випадки відхилення від цих норм, а відтак право на таємницю кореспонденції людини систематично зазнає втручань чи обмежень. Тож його захист є однією з найбільш гострих проблем як для України, так і для інших демократичних країн. Варто також зауважити, що для деяких суб'єктів це конституційне право зазнає певних трансформацій, пов'язаних із їхнім статусом. Якщо для одних, як-то для осіб, засуджених до позбавлення волі, прямо встановлено обмеження права на таємницю листування, телефонних розмов, телеграфної та іншої кореспонденції, то інші - наприклад, представники влади, користуються вищим імунітетом від незаконного чи свавільного втручання у таємницю кореспонденції. Тож дослідження питань забезпечення права на таємницю листування телефонних розмов, телеграфної та іншої кореспонденції окремих категорії осіб $\epsilon$ важливим для встановлення законності запровадження контролю їх спілкування.

() Л.В. Міхневич, 2020

${ }^{*}$ Liudmyla Mikhnevych, Ph.D. in Law, Associate Professor, Head of the Department of Kyiv National Economic University named after Vadym Hetman 